\title{
LEGAL STATUS OF THE VIRGIN ISLANDS DIVORCES
}

\author{
By Vern D. CaLloway, JR.*
}

\section{Introduction}

In recent months it has become increasingly popular among United States eitizens seeking divorees to forsake the time-honored trek to Reno, and head instead for the outlying territory of the Virgin Islands. This change in direction of the so called "divorce trade" is due to the comparative ease with which one can obtain a divorce decree and the attractions of the Islands. For those who can afford the trip, it is thought that two birds can be killed with one stone, so to speak: a divorce obtained and a restful vacation enjoyed.

By provision of Congress, the Legislative Assembly of the Virgin Islands was set up to enact legislation applicable to the Virgin Islands as a whole, ${ }^{1}$ the District Court of the Virgin Islands being given jurisdiction of all eases of divoree and annulment of marriage. $^{2}$

The current divorce law was enacted by the eighth Legislative Assembly of the Virgin Islands on December 18, 1944; approved December 29, 1944, by the acting Governor; and went into effect on January 28, 1945. The law gives as grounds ${ }^{3}$ for either party to obtain a legal separation, or to have their marriage contract dissolved, at the plantiff's option, for: adultery, cruelty, impotency, desertion for one year, habitual drunkenness for one year, conviction of a felony, insanity, and incompatibility of temperament. ${ }^{4}$

If the marriage was not celebrated in the district of the suit, before commencing action, the plaintiff must have been an inhabitant for a six-week period; such period being declared "Sufficient to give the court jurisdiction without regard to the place where the marriage was performed or the cause of action arose." When the dissolution judgment has become final, and after the expiration of

* 2nd year law student, Duke University; A.B. 1951, Duke University.

148 U. S. C. A. $\$ 1405 f$.

$=48$ U. S. C. A. $\$ 1406$ (4).

${ }^{3}$ Divorce luatws of the Virain Islands, Laws 1944, Bill No. $14 \$ 9$; Gordon Iretand \& Jesus de Galindez, Divorce in the americas, pp. 32-34 (1947); 39 KY. L. J. 289-316 (1951).

- Emphasis supplied.

- IRELAND \& GAIINDEZ, op. cit., supra note 3. 
time for appeal, either spouse may remarry again without further limitation of time. ${ }^{8}$

With the leniency of the divorce law in effect, plus the tourist attraction of the locale, it is little wonder that prosperous United States eitizens with the intent to sever marital relations are taking advantage of the new divorce mecca. The advantage of a divorce from a United States Federal court over the "quickies" from Mexico ${ }^{8}$ in contrast to the Nevada divorce-mill towns, and for Easterners, at least, the shorter distance-all add to the attractiveness of transacting such business in the tropic Islands. In fact, the short residence requirement coupled with the liberal incompatibility cause looks suspiciously like a deliberate tourist-trade bid. ${ }^{9}$

Although there are no reported Supreme Court decisions as of April 1953, under the present doctrine of the United States Supreme Court there is considerable doubt that a state court, or presumably any foreign court, would be precluded from collaterally attacking the finality of the decision of the jurisdiction giving the finding of domicil. ${ }^{10}$ Here then we come upon the problem. As the law now stands, what would happen to a Virgin Islands divorce decree if attacked by a suit in another state or territory?

- Tbid.

? The length of time of residency required in the different jurisdictions seems to run between six weeks and five years, with the majority being one year. 2 Vernikr, a arerican Fasml tuaws, Table XIII, Divorce and Separation, (1932).

As to grounds, New Mexico has a ground of "Incompatibility." N. M. STAT. ANN., $\$ 25-701(8)$. Alaska has ground of "Incompatibility of temperament." 3 ALASKA CoMrP. LAaws ANN., 1949, \$56-5-7(5). Florida statute reads: "Habitual indulgence by defendant in violent and ungovernable temper." 5 FLA. STAT. ANN. $\oint 65.04(5)$. Arkansas also has a liberal ground, "Where either party willfully deserts and absents himself from the other for one year without reasonable cause." 3 ARK. STAT. ANN. $\$ 34-1202$.

"It has been held that Mexican "mail order" divorces give no color of jurisdiction to the Mexican courts to grant divorce. The leading case holding such divorces to be nullities was Caldwell v. Caldwell, $298 \mathrm{~N}$. Y. 146, $81 \mathrm{~N}$. E. 2d 60 (1948). It was said in that ease that the Constitution requiring states to give full faith and credit to judgments of sister states had no relation to foreign nation decrees. See also, Tonti v. Chadwick, 1 N. J. 531, 64 A. $2 d 436$ (1949).

${ }^{\circ}$ However, the case of Burch v. Burch, 195 F. $2 d 799$ (3rd Cir. 1952), states that the incompatibility cause probably was taken over from the existing Danish Law at the time the Islands were purchased from Denmark by the United States.

10 is ' [I]nhabitant' and 'resident' as used in the [Virgin Islands] statute must be taken to mean 'domiciliary' and 'domicil' respectively." Burch $v$. Burch, $i d$. at 804 . 
"According to the usual Anglo-American rule, marriage is a status, a sufficiently permanent relation between the spouses that it has a 'real' existence, and can be treated .... as if it were a thing or res. ... [Marriage] is the legal position of the married person in the place in which he ... has a permanent home. Thus, under this 'status theory,' the power of the courts to destroy ... the relationship is based on the domicil of the spouses." "11

The difficulties, we find, crop up and compound when spouses take up residence in different jurisdictions.

Due to the lack of any uniformity in the divorce laws of the various states and territories of the United States, the only forces that have been applied for the recognition of divorces in one state by another are comity and the "Full faith and credit clause" of the Federal Coustitution.12 This clause provides that "Full faith and eredit shall be given in each state to the public acts, records, and judicial proceedings of every other state."13 This clause was implemented by act of Congress in 1789, which provided that properly authenticated records of judicial proceedings in one state shall have such faith and credit as they have by law or usage in courts of the state from which they are taken. ${ }^{14}$

Where both parties are domiciled in the jurisdiction of the forum, or where the defendant appears personally in an action brought by the plaintiff in his domicil, decrees have been accorded full faith and credit. ${ }^{15}$ The difficulty, and our problem, arises where the plaintiff takes up residence in the Islands, brings action there, claiming it to be his domicil (although it is not the lust bona fide marital domieil), the defendant domiciled elsewhere ${ }^{16}$ being 98.

1122 So. CaLIF. L. Rev. 155, 155 (1949). Also see 1953 WASH. U. L. Q.

12 Although comity depends on the states themselves, the Virgin Islands are a territory of the United States and necessarily are nnder the Constitution, the full faith and credit clanse applying the same as to any other state or possession.

${ }^{23}$ U. S. CoNsT., ART. IV $\$ 1$.

${ }^{14}$ Present code section: 28 U. S. C. A. $\$ 1738$, reads: "Such acts, records and jndicial proceedings ... shall have the same full faith and credit in every court within the United States and its Territories and Possessions as they have by law or usage in the courts of such State, Territory or Possession from which they are taken."

${ }^{25}$ Davis v. Davis, 305 U. S. 32 (1938); Sherrer v. Sherrer, 334 U. S. 343 (1948).

${ }^{20}$ American courts from early times departed from the English rule to the contrary, and held that a wife could have a separate domicil. Modern legisla- 
served only constructively by publication or otherwise, though by methods satisfying due process. ${ }^{17}$ We are dealing not with the purely domestic, semi-domestic, or wholly foreign divorce, ${ }^{18}$ but with the semi-foreign, where the plaintiff sues in other than the matrimonial domicil or regular home living place and the defendant remains in some other state or territory. ${ }^{19}$ There is no question that Virgin Islands divorees would be recognized in the various states when granted in cases where both spouses were resident with bona fide domicils in the Islands; and little doubt that full faith and credit would be granted or comity extended in cases where the plaintiff was a bona fide long term inhabitant of the Islands but defendant had removed from the Islands. ${ }^{20}$ Wholly foreign divorces are not granted. ${ }^{21}$

\section{Historical Background, Pre-Williams Cases}

The matrimonial domicil rule was early seen in Chesley v. Clayton, ${ }^{22}$ where husband and wife married and lived in West Virginia, $H$ moved to Colorado, $W$ refused to move, $H$ subsequently obtained a divorce in Colorado and the divorce was held invalid in Kentucky. Dictum from the case, however, suggested that the decree would have been valid if the formalities of service had been properly complied with.

This tentative rule flowered in the case of Atherton $v$.Atherton, ${ }^{23}$ where $H$ and $W$ married and lived together in Kentucky, $W$ moved to New York and $H$ got a Kentucky divorce. The decree was held

tion has done much to raise the legal rights of the wife to an equal plane with the husband. 31 IowA L. REv. 232 (1946). "The rule is that she [wife] may acquire separate domicil whenever it is necessary and proper that she should do so ... the proceeding for divorce may be initiated where the wife has her domicil." Cheever v. Wilson, 9 Wall 108, 124 (U. S. 1870). Also see, Bell v. Bell, 181 U. S. 175 (1901) ; Williamson v. Osenton, 232 U. S. 619 (1914).

${ }^{17} 22$ So. Carif. L. ReV. 155 (1949).

${ }^{18}$ Bell v. Bell, 181 U. S. 175 (1901).

2019 TEN. I. REv. 78 (1945).

${ }^{20}$ Since the domicil of the plaintiff would be anquestionable. See Williams v. North Carolina, 325 U. S. 226 (1945).

ax “. . judicial power to grant a divoree is founded on domicil. ... [T] domicil of at least one of the spouses must be within the state or territory in order to give courts of that state or territory power to dissolve the marriage." Burch v. Burch, 195 F. 2d 799, 804 (3rd Cir. 1952). Sce also, Williams v. North Carolina, 325 U. S. 226 (1945); Haddock v. Haddock, 201 U. S. 562 (1906).

22110 U. S. 701 (1884).

${ }^{23} 181$ U. S. 155 (1901). 
valid in New York and a bar to W's New York petition. Reasonable steps had been taken to notify $W$, failing that, constructive service was had on $W$ in Kentucky. The decision inferred that the fault was attributable to the deserting wife; therefore, the "matrimonial domicil" remained within Kentucky, the only situs of the marriage, and the plaintiff's domicil.

Haddock v. Haddock ${ }^{24}$ was the leading case from its decision in 1906 until the 1940's. This case extended the matrimonial domicil rule. The New York courts had refused to recognize and extend full faith and credit to a Connecticut divorce obtained by $H$ who had moved from New York to Connecticut and established a long term bona fide domicil. The Supreme Court upheld this position holding that Connecticut was not the matrimonial domicil, and there was neither personal service on, nor appearance by the wife in the Connectieut proceedings. Therefore, the Connecticut divorce was not entitled to be granted full faith and credit by New York, even though $H$ 's bona fide domicil was in Connccticut. The matrimonial domicil had remained with the wife because $H$ was the wrongful party. This decision all but knocked out one of the main props of semi-foreign divorces.

The case of Miller $\mathrm{v}$. Miller ${ }^{25}$ implies that perhaps a number of jurisdictions did not avail themselves of the Haddock ruling. In that case, the Iowa court, following a policy of extending comity to decrees of divorce from foreign states, said that if a decrec was "good on its face, a presumption of validity [arises], and burden of attack is on him who denies the same." 25 a

\section{The Williams Cases}

The long-standing tenure of the Haddock case doctrine was expressly overruled by the first Williams case. ${ }^{26}$ In this case a man and woman were charged with bigamous cohabitation in North Carolina after having obtained divorees from their respective previous spouses in the state of Nevada. The North Carolina Supreme Court had upheld the lower court conviction. ${ }^{27}$ The United States Supreme Court held that the establishment of a bona fide domicil in Nevada, not having been challenged by the North Carolina Court,

${ }_{24} 201$ U. S. 562 (1906); discussed in 54 YALE I. J. 806 (1945).

${ }^{25} 200$ Iowa 1193, $206 \mathrm{~N}$. W. 262 (1925).

25a Id. 206 N. W. at 265.

${ }^{20}$ Williams v. North Carolina, 317 U. S. 287 (1942).

${ }^{27}$ Williams v. North Carolina, 220 N. C. 445,17 S. E. $2 d 769$ (1941). 
the court of the latter state is bound by, and must recognize and show respect to, the Nevada decree. This was true although jurisdiction over the respondents had been obtained by substituted service, and the recognition of such divorces offended North Carolina policy.

So the first Williams ease restored the eonstructive service prop to foreign-divorce, holding that if the suing party, man or woman, is domiciled in the granting state, service by publication on the nonresident spouse is sufficient service. "The rule was now unmistakable that a foreign divorce grounded upon constructive service . . . was entitled to full faith and credit in all states.'"28 Matrimonial domieil paled in importance, but the question of bona fide domicil of the plaintiff was left open.

The Supreme Court of the United States remanded the case to the North Carolina Supreme Court which vacated the former judgment and ordered a new trial. ${ }^{29}$ After the new trial and conviction the North Carolina Supreme Court affirmed ${ }^{30}$ and the United States Supreme Court granted certiorari ${ }^{31}$ This time the record presented the precise question whether North Carolina had the right to refuse full faith and eredit to the Nevada divorce decrees because, contrary to findings of the Nevada court, the North Carolina jury had found no bona fide domicil was acquired in Nevada. The Supreme Court affirmed the North Carolina position, holding that North Carolina was entitled to find that petitioners did not acquire domicil in Nevada, and that the Nevada court was, therefore, without power to liberate the petitioners from amenability to the laws of North Carolina governing domestic relations.

In the second Williams case, the trial jury found that the defendants went to Nevada with the intent to get divorces and then to return immediately to North Carolina. The Supreme Court said that the judicial power to grant divorce jurisdiction was founded on domicil, a state having the authority to ascertain the existence of that crucial faet.

"As to the truth or existence of a fact, like that of domicil, upon which depends the power to exert judieial authority, a State not a party to the exertion of such judicial authority in another State but serionsly affected by it has a

2819 TENN. L. REV. 78, 81 (1945).

20222 N. C. 609,24 S. E. $2 d 256$ (1943).

30224 N. C. 183,29 S. E. $2 d 744$ (1944).

${ }^{31}$ Williams v. North Carolina [II], 325 U. S. 226 (1945). 
right, when asserting its own unquestioned authority, to ascertain the truth or existence of that crucial fact." 32

"But simply because the Nevada Court found that it had power to award a divorce decree cannot . . . foreclose reexamination by another state." ${ }^{33}$

The North Carolina Supreme Court had said that the jury was instructed that if the defendants went to Nevada with the requisite intent and actually acquired domicil there, though they later changed their minds and returned to North Carolina, then the courts of Nevada would have acquired valid jurisdiction and the decrees would have been entitled to full faith and credit. ${ }^{34}$

Williams (II) did not expressly overrule Williams (I), the court being careful to distinguish them. The Supreme Court did not return to the old concept of "marital domicil" but created two new expressions: "domiciliary origin" and "old domiciliary states." The result appears that the finding of domicil is a fact and such finding by one state's court is not binding on another's; all that is needed to disregard it being some evidence that the jury may reasonably conclude that there was no domiciliary intent when the decree was rendered. The Supreme Court seemed to leave the problem hanging on the rather vague term "domicil" and the finding of "jurisdictional fact."

The doctrine seems to emerge that foreign divorce grounded on construetive service plus bona fide domicil ${ }^{36}$ of the plaintiff must be recognized when based on the constitutional mandate of full faith and credit. But the states are left free to make inquiry as to whether the granting state had lacked proper jurisdiction. Since the granting state found bona fide domicil, the refusal of another to recognize the divorce is subject to review by the United States Supreme Court. ${ }^{37}$

\section{Post-Williams Cases}

As early as 1808, in Rose v. Himely, ${ }^{38}$ it was said that the full ${ }^{32} I d$. at 230. ${ }^{33} \mathrm{Id}$. at 234.

34 The Supreme Court cited Davis v. Davis, 305 U. S. 32 (1938) as the basis for its decision in the second Williams case.

${ }^{35} 31$ Iowa L. REv. 237 (1946); and 21 N. Y. U. L. Q. 457 (1946). For further treatments of the socond williams case see: 25 So. CAIIF. L. REV. 318 (1952); 19 TEMPLI I. Q. (1945); 29 A. B. A. J. 268 (1943).

${ }^{36}$ The second Williams case held that the wrong or fault of the person establishing domicil is immaterial to the jurisdiction.

${ }^{37} 6$ L.A. L. REV. 469 (1945).

${ }^{38} 4$ Cranch 241,269 (J. S. 1808), aff' $d$ in Thompson v. Whitman, 18 Wall. 457, 462 (U. S. 1873); and Haddock v. Haddock, 201 U. S. 562, 573 (1906). 
faith and credit clause did not extend to judgments granted by courts lacking the proper jurisdiction; and Williams (II) added that domicil, like other jurisdictional facts was open to inspection by a second state. This seems consistent with the principle of Conflict of Laws that judgments rendered without jurisdiction need not be accorded recognition by sister states, and that the second state may decide whether the first had jurisdiction to render judgment. $^{39}$ Esenwein v. Esenwein, ${ }^{40}$ although the main issue involved was whether $H$ 's divorce would cancel a prior support decree in favor of $W$ awarded by the Pennsylvania court, upheld the right of Pennsylvania to find that a Navada divorce decree lacked the jurisdictional prerequisite of bona fide domicil. ${ }^{41}$

Davis v. Davis, ${ }^{42}$ decided a few years prior to the two Williams decisions, had held that a wife who entered a personal appearance in H's Virginia divorce proceeding and contested his alleged domicil there was bound by the Virginia court's findings of jurisdiction, and could not collaterally attack them in the District of Columbia. ${ }^{43}$

In 1948 Sherrer v. Sherrer ${ }^{44}$ strengthened the Davis decision. The Supreme Court held that, where $H$ appeared personally in $W$ 's Florida divorce proceedings, and did not litigate the court's jurisdiction specifically, when he later sought a Massachusetts declaration placing in issue the validity of his wife's domicil at the time, the full faith and credit clause requirement barred his collateral attack on jurisdictional grounds. He had participated in the litigation and had, in effect, his day in court. The issue, under the circumstances, was no longer open. ${ }^{45}$

The Sherrer decision was strengthened by Coe v. Coe. ${ }^{46}$ The

30 Thompson v. Whitman, ibid.; Williams v. North Carolina, supra note 31.

${ }^{10} 325$ U. S. 279 (1945).

1 Eluggs v. Huggs, 195 F. 2d 771 (D. C. Cir. 1952); and Hobbs จ. Hobbs, 197 F. $2 d 412$ (D. C. Cir. 1952), are two recent Court of Appeals cases from the District of Columbia holding that divorce decrees not entitied to full faith and credit due to plaintiffs intention to return to the District of Columbia after acquiring a divorce.

$\therefore$ See note 15 , supra.

"Jurisdiction to grant divorce exists in any state in which at least one of the parties is domiciled. Restatearent, Conflict of Laws (1934), $\$ \$ 110,111$, 113 ; Restamenent, Judgrmants (1948 Supp.), $\$ 33$, Comment a; Goodrich, Confuct on Laws (3rd ed. 1949), §397, p. 127; 27 C. J. S., Divorce, $\$ 633$, p. 71.

“ See note 15, supra.

t5 25 So. Carin. L. REv. 318-329 (1952); Baer, The Aftermath of Williams vs. North Carolina, 28 N. C. L. REv. 265-290 (1950).

s6 334 U. S. 378 (1948). 
Sherrer and Coe cases rendered immunity to easy divorces from attack by spouses who appeared in the litigation.

"[But although not assailable] as between parties that does not necessarily mean the home state cannot prosecute for bigamy should one of the ... [parties remarry] and come back to live in the state of his true domicil." 47

Thus we see that the Supreme Court makes the divorce uncertainty worse by recognizing divisible-divorce. On the basis of Estin v. Estin $^{48}$ and Kreiger v. Kreiger, ${ }^{40}$ we see the court saying that regardless of the laws of the divorcing state, if under the law of the home state an ex parte decree does not terminate a prior support order, that order remains in effect despite foreign divorce. Thus, we see the Supreme Court saying that one can have a divorce recog. nized for some purposes and not for others.

In Johnson v. 1 Kuelberger, ${ }^{50}$ where a Florida divorce was attacked by the parties' daughter in New York, the court held that when, as in the Sherrer case, the defendant spouse appears in the divorce action, or is personally served, the (Florida) court's finding of jurisdiction may not be collaterally attacked in another state by anyone, if it is not subject to such attack in the divoreing state. In Cook v. Cook ${ }^{51}$ this position was strengthened, the court stating that "until Florida's jurisdiction is shown to be vulnerable, Vermont may not relitigate the issue of domicil upon which the Florida decree rests." Sutton $\nabla$. Lieb ${ }^{52}$ held that where $W$,was not personally served and did not enter appearance in a Nevada divorce suit, the divorce decree was subject to attack and nullification by the New York court for lack of jurisdiction over the parties, and the New York decree invalidating the Nevada divorce, entered in $W$ 's separate maintenance proceeding in New York, was entitled to full faith and credit in Nevada as well as Illinois where the instant suit was brought. But "Mllinois is free to decide . . the effect of New York's declaration of annulment on the obligations of the respondent, a stranger to that deeree." "52a

\section{Application to the Virgin Islands Decrees}

Examining our Virgin Islands divorce decrees in the light of these cases and the present Supreme Court standing as set forth in

428 N. C. I. REv. 265, 281 (1950).

18334 U. S. 541 (1948).

10334 U. S. 555 (1948).

ธo 340 U. S. 581 (1951).

52342 U. S. 402 (1952). 
the Williams cases and following, the picture is not bright and clear as it may seem at first blush. The holder of such a decree could be sure of the fact that as long as he remained in the Virgin Islands with the apparent intent to remain indefinitely he would be free of his former spouse. If he returns to his former home and his divorce should there be contested, even years later, by his former spouse, the state court in that state may find that there was no requisite domiciliary intent and refuse to recognize the divoree.

The most recent and apparently the only case involving a Virgin Islands divorce was Burch v. Burch, a Circuit Court case ${ }^{53}$ which construed the Virgin Islands statute. ${ }^{54}$ The court said:

"Jurisdiction to decree a divorce is not conferred upon the [District] court [of the Virgin Islands] by mere temporary residence of the plaintiff in the district which is accompanied by present intention on the part of the plaintiff to leave the Islands as soon as the divorce is granted."

The court went on to hold that the plaintiff had satisfied the requirement of domicil, as he had lived and and worked in the Virgin Islands for nine or ten months and was presently employed there with the intent to remain. The court construed the incompatibility of temperament to refer "to confliets in personalities and dispositions so deep as to be irreconcilable and to render it impossible for parties to continue a normal marital relationship with each other." "56 The court said that the ground did not include petty bickering and quarrels. The facts of the case, however, show that the defendantwife brought a counterclaim; therefore, this particular case would be foreclosed from later attack by the Davis decision, and a state court would be very hard put to find that the plaintiff did not have a bona fide Virgin Islands domicil. Therefore, this case does not offer a ready solution to our problem.

Most people currently combining divorce and diversion in the

195 F. $2 d 799$ (3rd Cir. 1952). "Courts of Appeals shall have jurisdiction of appeals from all final decisions of ... the District Court of the Virgin Islands, except where direct review may be had in the Supreme Court." 28 U. S. C. A. $\$ 1291$.

- Divorce Law of the Virgin Islands, Laws 1944, Bill No. 14, 99.

¿5 195 F. $2 d$ 799, 805 (3rd Cir. 1952). See also, Gage v. Gage, 89 F. Supp. 987 (D. C. D. C. 1950), which held that if the plaintiff is to establish a domicil so as to give the court jurisdiction for the purpose of divorce, there must be at least no intention of plaintiff to live elsewhere, and no intention to leave as soon as the divorce can be obtained.

vo 195 F. 2d 799, 807 (3rd Cir. 1952). 
southern clime do not intend to live there beyond the time it will take them to procure a divorce. Evidence of a round-trip ticket purchased before they left home might be enough to invalidate their divorees on their return home. Rice v. Rice $e^{57}$ held, in an action for declaratory judgment, that divorce in Nevada did not dissolve marriage in Connecticut, and evidence of a request for leave and a request for extension of that leave from the plaintiff's government job supported a finding that the plaintiff did not have a Nevada domicil and the Nevada court lacked jurisdiction. Moritz v. Morit $z^{58}$ held that the plaintiff could not qualify as a legal voter of New York and sue for divorce in the District of Columbia as a resident at the same time. Thus it would seem that about the only sure way to be secure in one's divorce would be actually to intend to stay when one went down to the Islands and be able to prove domieil.50

This alternative hardly would be satisfactory for most divorce seekers. The conclusion unhappily seems to be that unless and until the Supreme Court changes its present policy by deciding on a reasonable requirement to meet due process and grant full faith and credit, and substitute that for domicil, or a Uniform Divorce Law is created, ${ }^{B 0}$ those with Virgin Islands divorces will be subject to the perils of shaky and uncertain marital status.

s7 336 U. S. 674 (1949).

${ }^{68} 80$ F. Supp. 267 (Sup. Ct. D. C. 1936).

"Domicil is, "That place in which a man has voluntarily fixed the habita. tion of himself and family, not for a more special or temporary purpose, but with the present intention of making a permanent home, for an unlimited or indefinite period." BLACKS LAW DICTIONART, 3rd Ed., p. 608.

${ }^{80}$ There has been marked lack of support by the states in this movement. For a treatment of the history see, 1952 WASH. U. L. Q. 98. 